\title{
Beyond knowledge based intra organizational network
}

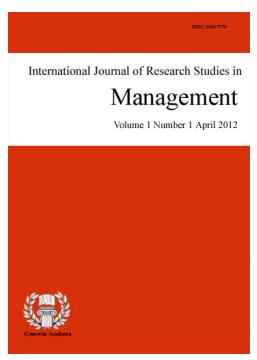

ISSN: $2243-7770$ Online ISSN: 2243-7789

OPEN ACCESS

\section{Abstract}

Studies concerning intra-organizational network was found very interesting since each research shared different findings. Factors such as timing, place, unit of analysis and methodology caused the results differs one another. This study used theory of friendship in addressing network phenomenon. After carefully analyzing several research report from 90's to early 2000 we come into conclusion the existence of knowledge-based network. The knowledge perspective found to have better explanation in examining long run network performance. By holding this as true and valid findings, we proposed to replace broker position to knowledge mediator, and change the position of producer, supplier, distributor and customer to the open source format. The research enclosed with proposing four basic quadrants that suitable for knowledge-based network structure.

Keywords: intra organizational; learning; network structure; investment based; knowledge based 


\section{Beyond knowledge based intra organizational network}

\section{Introduction}

For more than twenty years since Krackhardt and Brass seminal paper on intra organizational networks, many studies had been developed to found evidence of how the relationships might end up with better performance for all members. Some research was conducted on intra organizational elements such as decision making under networks (Carley \& Behrens, 1999; Gachet \& Brezillon, 2002; Cross et al., 2006; Koon et al., 2012; Mykkanen \& Tampere, 2014), structures (Ahuja \& Carley, 1998; Podolny \& Page, 1998; Molina, 2001; Lazer \& Friedman, 2007) and how power might effected its process (Holly \& Krackhardt, 2001; Pantelli et al., 2005). And the others tried to uncover the effectivity of networks (Brown \& Miller, 2000; Contractor \& Bishop, 2000; De Dreu \& Van Vianen, 2001; Katz \& Lazer, 2002; Van De Bunt, 2005). Although the results seem explainable, but most of them left the main course which is basic factor that make relationships last longer.

Snow (1993) in Managing $21^{\text {st }}$ Organizational Network already declared that investment-based network has the highest possibility to make the relationships longer. Describing the three types of networks; internal, stable and dynamic structure, the paper gave strong proponents to the role of brokers. Since every participant within network has to be operated under the law of scarcity then brokers will play important parts (Ahuja, 2000; Battilana, 2006; Battilana \& Boxenbaum, 2009). The main function would be sharing information to each member in enhancing transaction among networks.

In details, Snow argued that technological development shortened the information cycle due to decision making. Therefore for those who failed in acquiring the latest information, the need for brokerage service will arise. In further development, broker becomes the intermediary between producer, supplier, designer within one sets of network and market (for both customer and labor) as another set of network (Kleinbaum, 2012). Regarding to this position, the more information that broker had, the more power they might have. Unconsciously the process will lead to imbalance power among participants.

For example in the labor market, brokerage might play role as match maker between professional worker and company. Addressing the origin of broker as mere business organization, its performance mostly based on knowledge management process. If they can't manage it well, then it is plausible to serve the network upon its best capacity. This is why Kleinbaum (2012) strongly oppose the fact that brokerage might cause better organizational fitness. Conversely, if they were not acting professionally then organizational misfit might be the results; in the long run this may hurts the overall performance especially in the context of innovation (Aalbers, 2012).

Reality holds the same in the field of finance. Using investment-based network, more investors neither organizations nor individual has lied their future profitability to the broker for several reasons: (1) difficulties in predicting market trends, (2) lack of market information, and also (3) time constraints. Through some stand point, this makes investing activities more feasible to non-market timing players. But it also undermined future problems. Overconfidence broker might cause huge loss. Barber and Odean (2000) clearly explained that as organization, brokerages were found to eagerly seeking more profits due to the money invested. Therefore intention to use more professional judgement in the decision is getting higher.

Now let us consider if those things happen within network. The biggest possibility would be broken-up relationships. This might be the weakness side of using the terminology of investment in the context of intra-organizational relationships. One unique thing is that those broken pieces might create another network by sharing similar spirits (Tichy \& Fomburn, 1980; Turner \& Pratkannis, 1998; Van de Bunt, 2001; Newman \& Grivan, 2003; Taylor \& Doerfel, 2003). Those kinds of thoughts leaded us to current issues: (1) what is the triggering factor for long term loyalty within networks? And (2) at what type of structure does the factors might 
perform well.

Exploring non-investment based factors that might perform better in creating long term network is quite challenging. First signal would be offered by Von Krogh (2000), Walker (2000), Zeggeling (2003) through incorporating knowledge unto network research. Previous studies had succeeded in underlined importance of knowledge to deal with such current business issues. Most of the evidence supported the idea of Spinello (1998) known as value chain. Operating on limited resources required organization to provide product at its best and leave the other un-capabilities function to those who may perform at its best level.

The tautology gave us clear guidance to examine network through its purposes. If the purpose is to have better knowledge sharing mechanism, then the relationships might last longer than setting profit-sharing as the main spirit. Since from the last thoughts, when network no longer has the ability to provide profit, then the relationship will be broken (Anderson, 1994; Hakkansonn, 1995; Achrol, 1995; Sminia, 2007). Thus it is possible for us to proposed knowledge as ideal motivation to perform network.

In order to have objective opinion, we also carefully analyzed several cases that showed us the reality that for some participants they can't get fully advantage living in a knowledge network (Caruso et al., 2008; Salter et al., 2009). The existence of one party that has strong power compare to others might cause imbalance sharing process. Mostly the weak member will leave behind and acting as knowledge taker. Therefore we need to know which type of network that can minimize those negative consequences.

This paper tried to explain the twofold issues clearly. Using grounded theory approaches from qualitative methods, the study compiled some published research concerning intra-organizational network from 90's to early 2000. One final objective of the paper is to provide strong framework in performing long term network structure.

\section{Literature review}

\subsection{Motives of Intra-organizational Network}

Exploring the basic concepts of network started from social network proposed by Simon (1976), Freeman (1978) and Krackhardt (1996). These seminal article lead us to defined network in it's simply forms of formal and informal organization. This is true since most networks were not declared formally, only some of them are found to be stated in a formal way. Since this study used network as point of departure therefore we must clearly defined the terminology.

In order to examine network structure objectively, we will use the terms network in comprehensive way without trying to despise and treat it individually. This is found to be coherence with Krackhardt and Stern (1998); Moore (1992); Madhaven (1998) and Taylor and Doerfel (2003). With regards to the other perspectives, treating network for both formal and informal relationship lead us to the basic definition of how it created.

Network was formed by several organizations who shared the same interest (Van Alstyne, 1997; Borgatti \& Foster, 2003; Schienstock, 2009; Martin, 2013). Some will say that the interest of getting higher profit by operating at the most productive way could be the best reasons. For example: two food and beverages companies agreed in selling their product on a package, or airplane tickets that were sold on a bundled basis with flight insurance. In some cases, marketing collaboration resulted on higher profitability among members. Therefore numbers of researcher had recorded those who succeed and used it as benchmark (Tarricone \& Luca, 2002; Corwin et al., 2012; Hatton, 2014).

The complexity arose when economic turbulence due to the implementation of free-market in some regions. Several studies on strategic management found that the most competitive power lies on the synergy among players. When members failed to achieved synergy then the negative impact would be shared as burden within networks. At the case of financial merger and integration, Berger (2011) found that at least $30 \%$ of the combined 
organizations failed to synergize one another. The findings supported Gold (1998) that successfully described efforts to achieve synergy as the hardest part of organization's life stages. And mostly, the triggered comes from failure in unfirming perception among decision makers.

Now let us briefly analyze to the success story. Tsai (2001) clearly explained that the key success factor for creating synergy within intra-organizational network was found on the effectiveness of knowledge transfer among participants. Each member must share their best, accurate and updated information to the networks. At some points we might think that the conclusion is too ideal for current business environment. Business arrogances, authority and power must play an important role within networks. Since naturally, business organization is no more than sets of human that tried to achieve the same goals. This means that desire to have advanced position than other must exist.

Lasker (2001) stated that the great synergy within network requires good combination of each other strength in accordance with all members. The process was not simple. It is found as time consuming, resource intensive, very difficult and sometimes lead to frustration (Cheadel, 1997; Mitchell \& Shortell, 2000). To deal with such negative things, every organization must carefully consider before deciding to join in intra organizational network. Factors that should be taken into considerations are: (1) similarity of vision and goals, (2) the power of trust, (3) willingness to share organization strength and power, and (4) good communication skill (Hakanson \& Snehota, 1995; Lasker, 2002). Moreover, Snehota mentioned that in order to achieve the best performance, each member within networks must succeed in building up relationships among others. Network performance was actually based on effective partnerships among members since it counted for trust, persistency, responsibility, and willingness to sacrifice for others to get future mutual benefits.

Using that concept in explaining network phenomenon, it is just for us to proposed one hypothetic opinion that investment-based network can't hold the relationship in the long run and at the same time carefully addressing knowledge-based as the ideal motivation.

\subsection{The role of Partnership and Friendship}

Up to present, research on the knowledge-based network is still limited. Due to this constraint, let us examine the role of knowledge sharing needs for positive partnerships. Wildrige (2004) conducted literature review for factors that creates good partnership. The study found that the factors can be categorized into six subsets: (1) environment, count for history of past collaboration and social climate. Intra-organizational partnerships on developed countries found to be more stable than in under developing one since equality of power exists. (2) Regarding membership, counted for mutual respect, understanding, trust, and ability to compromise. (3) Related to process and structure where every member must see network as their own. (4) Communication that sought to be effectively deploy among members through openness at high frequencies. (5) Sharing the same spirits and (6) equality of resource distribution capabilities. One unique finding of the research is that among those six factors, most organization identified as putting the term sharing the same spirits as the most important thing, where good communication skill and mutual respect play as another important factors.

Regarding those findings, one might questioned is it possible to form intra-organizational network from converting friendship into partnership. Some would agree that it is possible. As many researchers conclude that the key for the best network performance lies on the strength of both strong and weak ties (Granovetter, 1973, 1983; Krackhardt, 1992; Baer, 2010), then we may use theory of friendship in performing network.

Based on the theory, friendship needed more than understanding between parties. It also complemented by tension that created dialectical contradiction which leads to a higher level of mutual understanding (Siversten, 2003). Rawlins (1992) identifies two general classes of dialectical in friendship: (1) contextual and (2) interactional. For simplicity, we tend to define contextual dialectical as trade-off between private and public, and also between ideal and the reality. Meanwhile interactional dialectics address the distortion in communication that leads to different opinion. One unique fact from interactional dialectic is efforts which each member perform 
good behavior among others and try to exclude from conflict. Naturally, they will manage all conflicts to sustain the relationship.

As business entities, each member within network shares their private domain in financial term. They are seeking for maximum profits. But consciousness to live within friendship and partnership with other player sometimes forced them to act at the best interest (which later called public domain). Having that kind of awareness was believed as the succeeded dialectical inter-organization. This is logically accepted since organization must delegated teamwork to perform any critical task. And when the critical task require them to have good collaborations, then one teamwork from organization A will be connected to one teamwork from organization B (see figure 1). This mechanism can be extended from one network into another set of network (see figure 2).

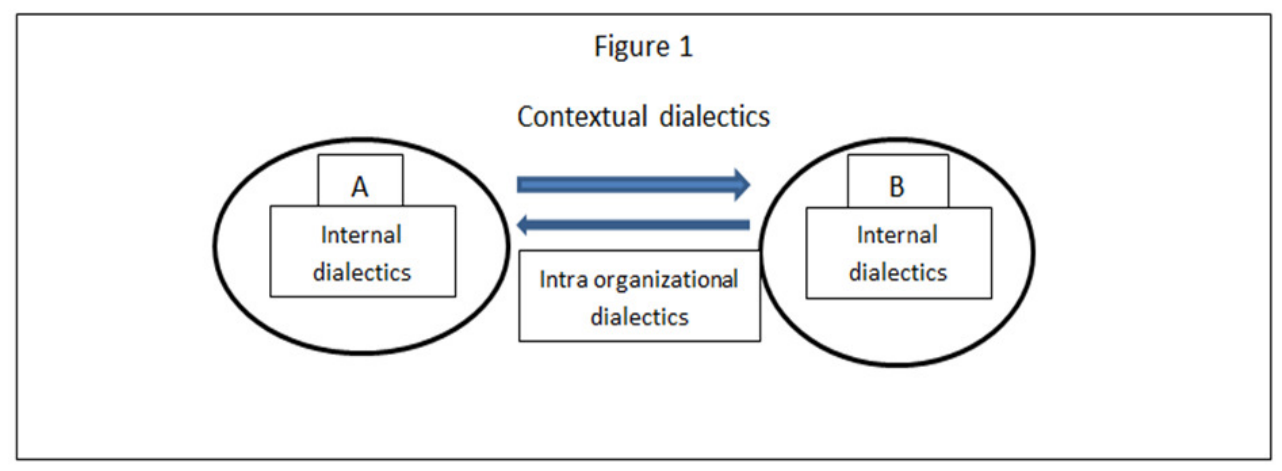

Figure 1. Contextual dialectics

Internal dialectics on each organization stands for a fully compromised mindset among teamwork. Several trade-off can be found during the process: (1) shared of idealism between members on teamwork. Although every task will be perform based on standard operating procedure, but as organization gave highly appreciation to knowledge transfer, then undocumented tacit knowledge found to played important role in deciding the best method of work (Styhre, 2004). (2) Shared of divisional point of interest. Even internal competition has never been announced formally, but accomplishing mission well might be the best self-appreciation at divisional context. Having collaboration with another organization can blurred individual performance. That is why trade-off found to be very important. (3) Strategic action to build up organization brand image. This must be the hardest trade-off for internal dialectics context.

Let us consider the internal dialectics happened at the member on Apple or Samsung network. Though they have the greatest contribution to the network by providing chips for the smartphone, but still the product will be produced on the leader's name. The network might highly appreciate the brand name, but it doesn't hold on the customer perspectives. Interestingly, dialectics ends up with one strategic decision as the results of the true trade-off. Another result from the dialectics process is the full list of incapability. This is the reasons why they will join collaboration with other organization.

As A and B starts to have collaboration, then another dialectics took place. At this stage, one organization found to perform dialectical with its partner. This is what we call intra-organizational dialectic stage. Upon the stage, every participant tried to get along with another player in terms of vision and work culture. Sometimes conflicts and reconciliation might happen as they grew to maturity level. If they agree to manage the relationship in an open system, then the possibility to leave the network can be found at any time. But for particular reasons, they tend to preserve the relationship for longer time. Thus open system means that the network will always open to those who share the same interest.

Figure 2 tried to explain the phenomenon. After performing intra-organizational at one network, they may develop another network-collaboration. Actually the same dialectics may happen but with one additional factor namely organization arrogance. Since the collaboration can be applied between well-known network and 
non-famous one, then the trade-off will be clearer. Those well-known networks will trade its arrogance with the mutual helps from non-famous network. Whenever the trade-off succeed then the collaboration will took place. But when it failed to reach common decision, then most probably the collaboration will not happened.

Contextual dialectics will be complemented by interactional dialectics. In this context, Rawlins (1992) argue that friendships are potentially fraught with ambiguity due to interpretation of others form of communication and behavior. The same thing might be happened in the context of intra-organizational networks. Therefore, dialectics that comes from interaction between one another should be treated for the best interest. This is the ties that make network stronger.

Another strength point from succeed interactional dialectics is honesty that act as virtue and protective understanding to avoid making loss each other. This spirit shared opportunities that one member will help other to develop its capabilities. That's why knowledge sharing process would be advantageous (Paulin, 2012). The needs to open its network system to have collaboration with another network occurred upon this stage. Eagerness to explore more knowledge leads one network to expand their collaboration without trying to recruit member from others. This is the dynamic effect of living on open system environment.

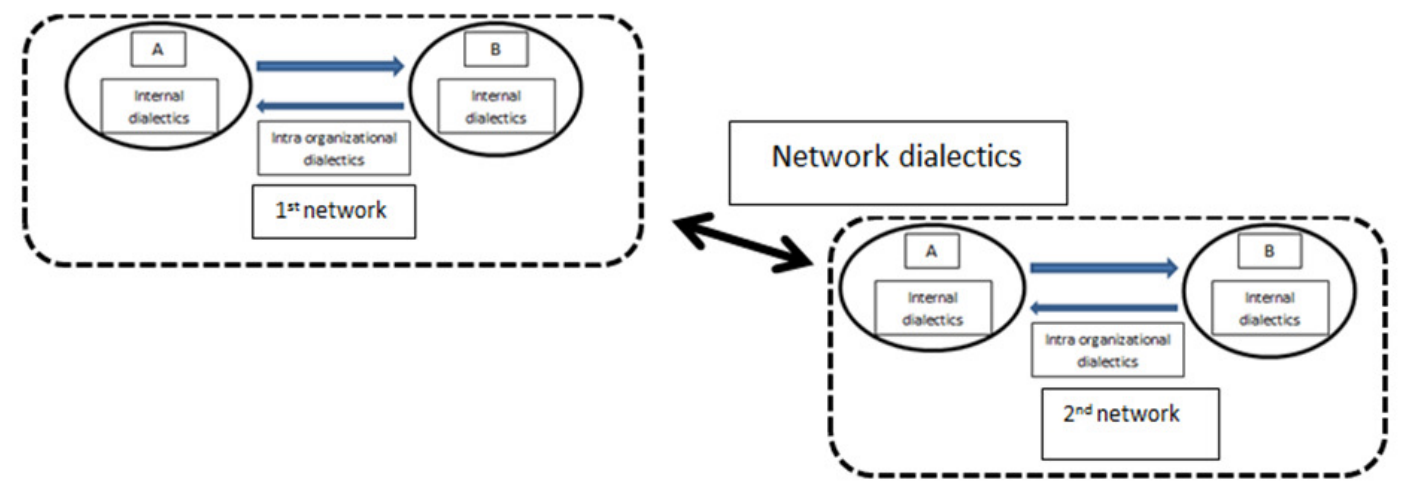

Figure 2. Extended contextual dialectics

In summary, this section succeeded in providing arguments that investment-based network must be replaced by knowledge-based intra organizational network. This is because network needed strong ties which are the spirit of friendship and partnership and knowledge-sharing motivation. As consequences of living on an open system environment, network may expand to have collaboration with other network by some acceptance un-written rules. Before having the relationships, there are some dialectical stages that should be solved. And sometimes, trade-off among interest played an important role as future tie. One possible constraint that might arise is motivation to change the open system to the closed system. It will diminish the spirit of improvements.

\section{Finding and discussion}

\subsection{Knowledge-based network structure}

Identifying the ideal structure that allows the most effective knowledge sharing happen was not simple. Several factors must be taken into consideration, such as knowledge transfer process, ties of the network, knowledge level among members, and some financial factors (Reagan \& Zuckerman, 2001; Reagan et al., 2003; Nadler et al., 2003). Therefore this study limit themselves by considering knowledge transfer process, without further consideration of using unit analysis for both formal and informal network.

Research that tried to find the association between network structure and knowledge transfer has become trending topics for the last three decades. This study had carefully review several findings offered by Uzzi (1996, 1997, 1999), Hansen (1999, 2002), Ingram and Roberts (2000), Reagan and Zuckerman (2001), Snow (1993) 
and Tsai (2001). One interest finding is the facts that knowledge can be transferred from one member unto another through variety of mechanism. It means that as long as every participant within network understands their role in knowledge sharing then the mechanism will operate.

Holding that true, at the early stage of network development, each member tried to have an equality basis in terms of expertise and authority. This might be the possible cause for conflict. But using network types offered by Snow (1993), there are some possibility that network will assign one participant to act as broker. On its origin, broker act as mediator by providing information to all parties due to resource allocation. In the same way, we may adhere intermediary as the play maker namely knowledge mediator (see figure 3). Thus adopting open system concepts, knowledge mediator will be responsible to provide a fair mechanism in knowledge transfer among members. And the only tie that makes transfer process more productive is the loyalty.

At this point, it is too early to have strong conclusion regarding loyalty. One basic argument is that each member might have different absorptive capacity in knowledge sharing process (Reagan, 2000). Just like human, organization tends to be more acceptable to certain area that they already know. Conversely they become reluctant to area that didn't covered by its expertise. If this happen, then the true knowledge transfer does not exists (Rogers, 1995; Tsai, 2001). This would be the important task of knowledge mediator. They are not only providing database needed for the process but also has to share something that might trigger the mechanism. Taken this into account, we may conclude that the network must be dynamic to live on open system environment.

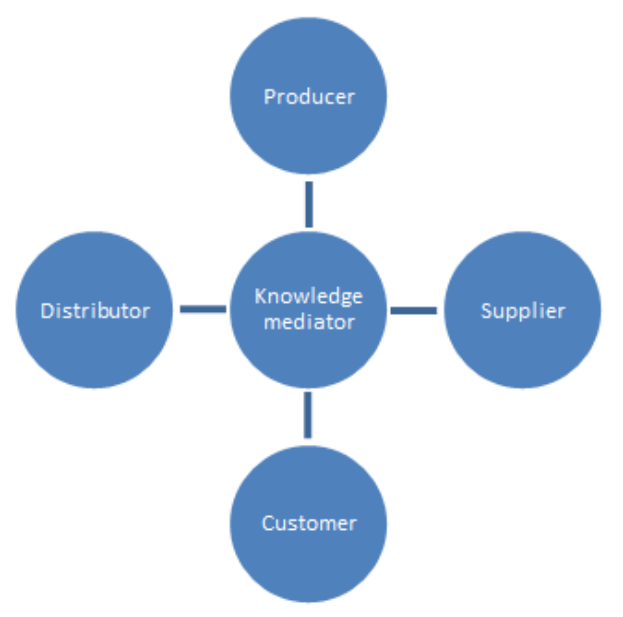

Figure 3. Components of knowledge-based network

Recent studies done by Reagans and Zuckerman (2001), Burt (2002), Gargulio and Rus (2002) indicates the importance of social cohesion and network range. Deeper relationships among members allow some human factors to be applied. Teamwork from one organization tends to help other teamwork from another organization for no return. This is the basic spirit for mutual cooperation in the next stage.

Another explanation that supported social cohesion was proposed by Coleman (1990), Paulin (2012) and Harison (2012). Each member was being motivated to share their knowledge for some social norms. When the other member in the same network had identified that there is a participant that refused to join the sharing process then the social punishment will took place. They will share the information to all parties and most probably become stigma that last longer. Finally they will rejected by the networks.

The second point is network range. Since knowledge is intangible assets, then it may flow freely inside and outside organization. Moreover, it also may fly to other networks. But in one condition: there should be no strong barriers. Zelmer-Bruhn (2003) explained that knowledge transfer across organizational boundaries can cause different interpretations of the same idea and also cost some disruption. Language barriers, different knowledge background may act as the critical constraint for knowledge-based network. Therefore every 
participant must be able to perform communication at a better quality (Borgatti \& Cross, 2003).

Good communication process can only happen in short range. Level of frequencies and intimacy will lead to the common understanding among parties. But we can't exclude to those outsider that may have the chance to join the process. If one organization from other set of network have the ability to absorb the knowledge well then we might have evidence that long range network should be taken into considerations.

For example, on the context of intra-nations relationships, there are lots of facts that the hackers act as a productive outsider that tried to absorb knowledge from target effectively. At some cases, they perform the action very well. But they also failed in other cases.

Putting the twofold concepts altogether, one must carefully selected the best network structure for knowledge-based inter-relations. Ignoring those two factors will creates so many distractions that weakened network performance in the long run.

Now let us revisiting the three networks-types proposed by Snow (1993) which are internal, stable and dynamic networks. By addressing rapid development in computer and communication technology, internal network may represent the type that lives in closed system environment. Conglomeration might be the best example for expressing how the network operates. The second type characterized by implementing closed system only for the member of core firm while opening widely on the supplier side. This type usually tends to protect their basic formulas. And the third type is the one who live on the open system environment.

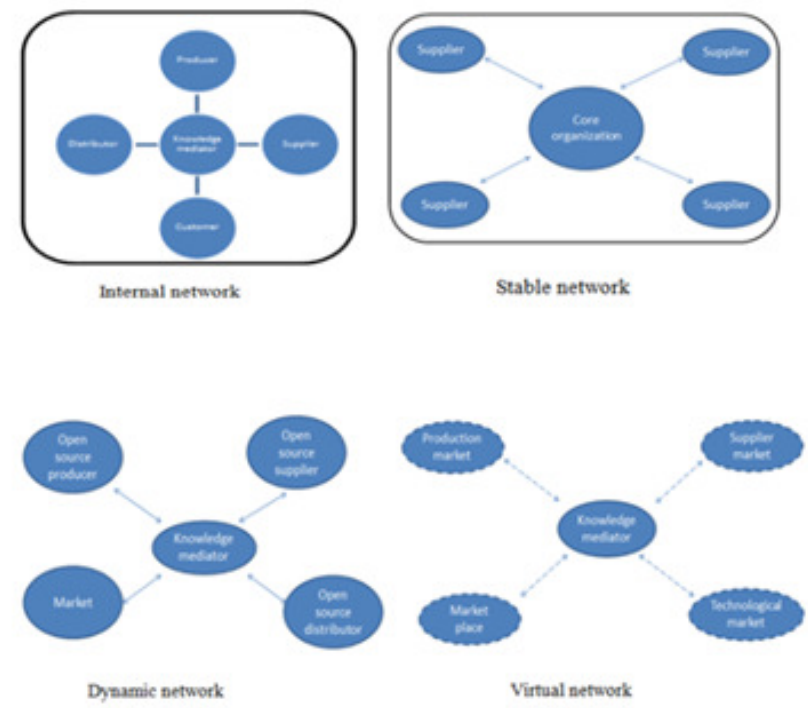

Figure 4. Type of network

By considering the vast development and the use of internet as knowledge based sharing media, we strongly proposed the fourth structure namely virtual network. Although the terms virtual defined as non-physical things, but we still can examine it in terms of networks. It is found to use open source that allowed all parties to join the knowledge exchange due to some acceptances rules. This informal structure was found to be well operated within system that has no ties except the similar interest. Therefore only knowledge mediator is the one who stays in the network. But the other parties share the same rights and equality to be tied in or release from network.

For a brief explanation, one might said that there are some similarities between dynamic and virtual network. But actually there is huge difference. First, virtual network found to have semi-formal platform where each member voluntarily give themselves as part of network. Knowledge mediator set up rules that should be accepted by the other participants. If member found no objections then they may accept the agreement. Although in some instance it is provided under the law system but every party gave appreciation to the free-will action. 
They may release-off from the network at any given time.

Secondly, we tend to use the terms of market to represent players in virtual network since it has been operated virtually. For example at the customer side, we use the term market place where every potential customer might come and go at any-time, any-where and for any-reasons. The only thing that makes the network operates in a more dynamic way is the additional role performed by technological market. They set up some technological platform and at the same time they might provide lots of raw data as basic material to be produced by knowledge mediator. Basically every participant may have interaction among them, but there is no guarantee that the quality will as high if knowledge mediator took position. The free-will of running away from network is the reasons why it should be perform this way. Thus the spirit must be open-system environment.

\subsection{Proposed structure}

Now we come to the last proposed idea within papers. Considering the two important factors: social cohesion and network range, we then could identify the appropriate network structure which fit for each possible conditions, see figure 5 for more details.

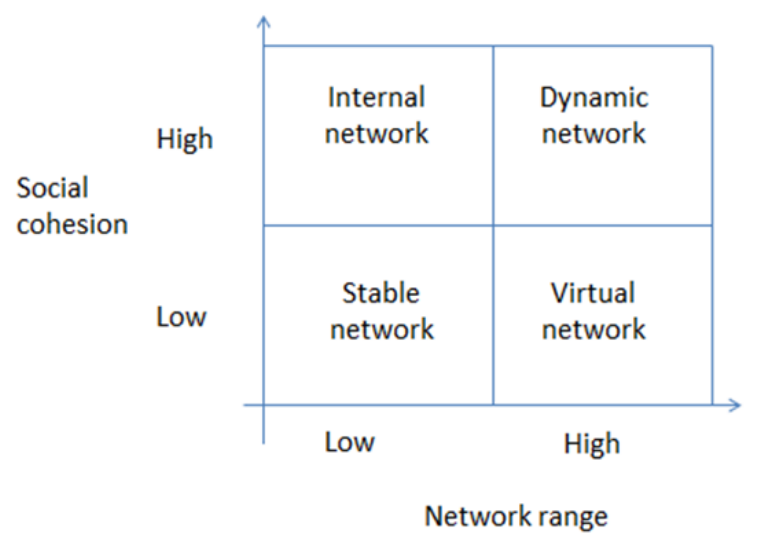

Figure 5. Proposed network structure quadrants

Type of network that ideal for low social cohesion within low network range is stable network. The reason is just because stable network could be characterized by having moderate ties. Since most stable network operates on a formal basis, each member found to response naturally. Some would say that this type of network can be finds to those networks that already come to maturity level on its life cycle. Without justifying the opinion, our proposed quadrants showed that there are possibilities for this type of network to have knowledge-sharing mechanism.

If one day the range expanded wider, then the type of network should be change into virtual one. We are not trying to say that this type should perform better than the stable one but it's a matter of using proper structure in order to have knowledge sharing mechanism running.

Having been operated in virtual condition, network must reorganize the role of each party. For some reasons, we have to admit that it will cause lots of problem since they have to be more open to the environment than before. Recruiting another type of market to join the network would be the most difficult task. More dialectical process will took place and sometimes tend to increase the level of social cohesion. If that happen then network will shift to dynamic type. After succeed in building up close friendship and partnership with members from open source market, network might carefully selected new participants. Unconsciously they are found to setting up another network with dynamic characteristics.

So, how about the internal network? The only thing that should be considered is that it only succeeded in operating through low range of network. High social cohesion means that dialectic process found to be more complex since in most cases member had experience operating on a comfort zone. Reluctances to widen the 
range may act as huge constraint but again, we can't say that this type is worse.

Recall the dyadic system proposed by Kadushin (2004) as organization developed unto maturity level, changes are easy to be found. Knowledge has admitted to have strong role in creating the changes (Dzunic, 2012). Further generation that leads the organization sometimes completed the mechanism with new non-tacit science. By good collaboration with tacit-knowledge experience, they may set the new rule, having clear sophisticated filtering procedure to be operated in low range of network or minimize the cohesion by maintaining the range.

\section{Future implication}

This study recognized two major future implications. First, we present the emergence evidence that investment-based network must be replaced by knowledge-based. This required many changes ranging from the participant, the rule and structure. Brokerage position in traditional approach now has been taken by knowledge moderator. As knowledge intermediary, they share the most important responsibility to triggered sharing mechanism among members. That's why we strongly suggest that each network must carefully selected mediator with proven-track reputation. Second, network can choose which type they should operates due to twofold dimensions: (1) social cohesion and (2) network range. With the four quadrants, organization may evaluate itself and decided to which part of structure they will grow.

As consequences of living under open system environment, networks have the opportunity to develop in a dynamic dyadic system. This is why exploring intra-organizational network always be the most interesting and arguable topics. Future research may be conducted to have the empirical evidence to the existence knowledge-based network. The main objective is to strengthen the basic academic tautology for organizational theory. Sociology and communication studies needed to measure level of social cohesion accurately. Moreover, network analysis using clustering statistical methods somewhat could be helpful in mapping the range. By having all evidence on one research paper, we can have benchmark how to manage the network in longer time.

\section{Conclusion}

Examining intra-organizational network using friendship theory lead us to identified that the key success found at the productive dialectic inter and intra organization therefore we might proposed to complemented investment-based network to knowledge-based. This required major changes among participant by raising the role of knowledge mediator. In the future, they will play important part in managing network. Treating network through theory of friendship we come to the conclusion of four quadrants based on twofold dimension: social cohesion and network range. They share the same position without considering which quadrants would be the best. Future research may be directed to those directions so that we might have proper pathways of developing networks.

\section{References}

Aalbers, H. L. (2012). Organizing intra-organizational networks for innovation. Unpublished Dissertation, University of Groningen, Groningen, The Netherlands.

Achrol, R. (1997). Changes in the theory of inter organizational relations in marketing: Toward a network paradigm. Academy of Marketing Science, 25(1), 56-79. http://dx.doi.org/10.1007/BF02894509

Ahuja, M. K., \& Carley, K. M., (1998). Network structure in virtual organization. Journal of Computational and Mathematical Organization Theory, 3(4), 1-32. http://dx.doi.org/10.1111/j.1083-6101.1998.tb00079.x

Anderson, J., Hakansson, H., \& Johanson, J. (1994). Dyadic business relationships within a business network context. Journal of Marketing, 58(October), 1-15. http://dx.doi.org/10.2307/1251912

Baer, M. (2010). The strength-of-weak ties perspective on creativity: A comprehensive examination and extension. Journal of Applied Psychology, 95(3), 592-601. http://dx.doi.org/10.1037/a0018761

Barber, B. M., \& Odean, T. (2000). Trading is hazardous to your wealth: The common stock investment 
performance of individual investors. The Journal of Finance, 55(2), 773-806. http://dx.doi.org/10.2139/ssrn.219228

Battilana, J. (2006). Agency and institutions: The enabling role of individuals' social position. Organization, 13(5), 653-676. http://dx.doi.org/10.1177/1350508406067008

Battilana, J., Leca, B., \& Boxenbaum, E. (2009). How actors change institutions: Towards a theory of institutional entrepreneurship. Academy of Management Annuals, 3(1), 65-107. http://dx.doi.org/10.1080/19416520903053598

Berger, R. (2011). Synergy management for successful post-merger integration. Management summary. Ronald Burger Strategy Consultant.

Borgatti, S. P., \& Foster, P. C. (2003). The network paradigm in organizational research: A review and typology. Journal of Management, 29(6), 991-1013. http://dx.doi.org/10.1016/S0149-2063(03)00087-4

Borgatti, S., \& Cross, R. (2003). A social network view of organizational learning, Management Science, 49, 432-445. http://dx.doi.org/10.1287/mnsc.49.4.432.14428

Brown, T. M., \& Miller, C. E. (2000). Communication networks in task-performing groups: Effects of task complexity, time pressure, and interpersonal dominance. Small Group Research, 31(2), 131-157. http://dx.doi.org/10.1177/104649640003100201

Burt, R. S. (1992). Structural holes: The social structure of competition. Cambridge, MA: Harvard University Press.

Caruso, H. M., Rogers, T., \& Bazerman, M. H. (2008). Boundaries need not to be barriers: leading collaboration among groups in decentralized organizations. Harvard Business School.

Cheadle, A., Beery, W., \& Wagner, E. (1997). Community based health promotion - State of the art and recommendations for the future. American Journal of Preventive Medicine, 13, 240-253.

Coleman, J. S. (1988). Social capital in the creation of human capital. American Journal of Sociology, 94, S95-S120. http://dx.doi.org/10.1086/228943

Coleman, J. S. (1990). Foundations of social theory. Cambridge, MA: Harvard University Press.

Contractor, N., \& Bishop, A. P. (2000). Reconfiguring community networks: The case of Prairie KNOW. In T. Ishida (Ed.), Digital cities: Technologies, experiences, and future perspectives. Lecture notes in computer science (pp. 151-164). Berlin, Germany: Springer-Verlag. http://dx.doi.org/10.1007/3-540-46422-0_13

Corwin, L., Corbin, J. H., \& Mittlemark, M. B. (2012). Producing synergy in collaborations: A successful hospital innovation. The Innovation Journal: The Public Sector Innovation Journal, 17(1), 2-16.

De Dreu, C. K. W., \& Van Vianen, A. E. M. (2001). Managing relationship conflict and the effectiveness of organizational teams. Journal of Organizational Behavior, 22(3), 309-328. http://dx.doi.org/10.1002/job.71

Dzunic, M., Boljanovic, J. D., \& Subotic, J. (2012). The importance of concepts of knowledge management and learning organization in managing the knowledge-flow in organizations. In Management, knowledge and learning international conference (pp. 301-311). Retrieved from http://issbs.si/press/ISBN/978-961-6813-10-5/papers/ML12_075.pdf

Goold, M., \& Campbell, A. (1998). Desperately seeking synergy. Retrieved from https://hbr.org/1998/09/desperately-seeking-synergy

Granovetter, M. S. (1973). The strength of weak ties. American Journal of Sociology, 78(6), 1360-1380. http://dx.doi.org/10.1086/225469

Granovetter, M. S. (1983). The strength of weak ties: A network theory revisited. Sociology Theory, 1, 201-233. http://dx.doi.org/10.2307/202051

Hakansson, H., \& Snehota, I. (1995). Developing relationships in business networks. Routledge, UK.

Hansen, M. T. (1999). The search-transfer problem: The role of weak ties in sharing knowledge across organization subunits. Administrative Science Quarterly, 44, 82-111. http://dx.doi.org/10.2307/2667032

Hansen, M. T. (2002). Knowledge networks: Explaining effective knowledge sharing in multiunit companies. Organization Science, 13, 232-248. http://dx.doi.org/10.1287/orsc.13.3.232.2771

Harison, A., \& Qing H. (2012). Knowledge transfer within organizations: A social network perspective. In 2012 45th Hawaii international conference on system sciences (pp. 3766-3775). IEEE. 
Prasetyo, A. H., \& Hu, J.

http://dx.doi.org/10.1109/HICSS.2012.410

Hatton, L. (2014). A synergistic approach to small business entrepreneurship. Journal of Management and Marketing Research, 17(4), 336-347.

Holly, R., \& Krackhardt, D. (2001). Intra organizational networks. In J. A. C. Baum (Ed.), Companion to organization (pp. 58-74). Oxford, UK: Blackwell.

Ingram, P., \& Roberts, P. (2000). Friendships among competitors in the Sydney hotel industry. American Journal of Sociology, 106, 387-423. http://dx.doi.org/10.1086/316965

Kleinbaum, A. M. (2012). Organizational misfits and the origins of brokerage in intra firm networks. Administrative Science Quarterly, 57(3), 407-452. http://dx.doi.org/10.1177/0001839212461141

Koon, A. D., Nambiar, D., \& Rao, K. D. (2012). Embedding of research into decision making process. Alliance for Health Policy and Systems Research, India.

Krackhardt, D. (1992). The strength of strong ties; The importance of philos in organizations. Network and organizations: structure, form and action. Harvard Business School Press, Boston.

Krackhardt, D., \& Brass, D. J. (1994). Intra-organizational networks: The micro side. In S. Wasserman \& J. Galaskiewicz (Eds.), Advances in the social and behavioral sciences from social network analysis (pp. 209-230). Beverly Hills: Sage. http://dx.doi.org/10.4135/9781452243528.n8

Krackhardt, D., \& Stern, R. N. (1988). Informal networks and organizational crises: An experimental simulation. Social Psychology Quarterly, 51(2), 123-140. http://dx.doi.org/10.2307/2786835

Lasker, R. D. (2002). Maximizing the power of partnerships: A team-based workshop. Community Campus Partnerships for Health conference. Miami, Florida.

Lasker, R. D., Weiss, E. S., \& Miller, R. (2001). Partnership synergy: A practical framework for studying and strengthening the collaborative advantage. The Milbank Quarterly, 79(2), 179-206. http://dx.doi.org/10.1111/1468-0009.00203

Lazer, D., \& Friedman, A. (2007). The network structure of exploration and exploitation. Administrative Science Quarterly, 52, 667-694. http://dx.doi.org/10.2189/asqu.52.4.667

Madhaven, R., Koka, B. R., \& Prescott, J. E. (1998). Networks in transition: How industry events (re)shape inter firm relationships. Strategic Management Journal, 19 (5), 439-459. http://dx.doi.org/10.1002/(SICI)1097-0266(199805)19:5<439::AID-DIA952>3.3.CO;2-U

Martin, A. \& Van Bavel, R. (2013). Assessing the benefits of social networks for organizations. JRC Technical Reports. European Union.

Mitchell, S. M., \& Shortell, S. M. (2000). The governance and management of effective community health partnerships: A typology for research, policy and practice. The Milbank Quarterly, 78(2), 241-89. http://dx.doi.org/10.1111/1468-0009.00170

Molina, J. L. (2001). The informal organizational chart in organizations: An approach from the social network analysis. Connections, 24(1), 78-91.

Moore, G. (1990). Structural determinants of men's and women's personal networks. American Sociological Review, 55(5), 726-735. http://dx.doi.org/10.2307/2095868

Moore, G. (1992). Gender and informal networks in state government. Social Science Quarterly, 73(1), 46-61.

Mykkanen, M., \& Tampere, K. (2014). Organizational decision making: The Luhmanian communication perspective. Journal of Business Studies Quarterly, 5(4), 235-265.

Nadler, J., Thompson, L., \& Van Boven, L. (2003). Learning negotiation skills: Four models of knowledge creation and transfer. Management Science, 49, 529-540.

http://dx.doi.org/10.1287/mnsc.49.4.529.14431

Newman, M. E. J., \& Girvan, M. (2003). Finding and evaluating community structure in networks. Working Paper. University of Michigan.

Panteli, N., Tsiourva, I., \& Modelly, S. (2005). Intra organizational connectivity and interactivity with intranets: The case of pharmaceutical company. Working Paper. University of Bath, School of Management. UK.

Paulin, D., \& Suneson, K. (2000). Knowledge transfer, knowledge sharing and knowledge barriers - three Blurry terms in KM. The Electronic Journal of Knowledge Management, 10 Issue 1, 81-91.

Podolny, J. M., \& Page, K. L. (1998). Network forms of organization. Annual Review of Sociology, 24, 57-76. 
http://dx.doi.org/10.1146/annurev.soc.24.1.57

Reagans, R., \& Zuckerman, E. (2001). Networks, diversity and performance: The social capital of R\&D units. Organization Science, 12, 502-517. http://dx.doi.org/10.1287/orsc.12.4.502.10637

Reagans, R., Zuckerman, E., \& McEvily, B. (2003). How to make the team? Social networks vs. demography as criteria for designing effective projects. Working paper, Columbia University Graduate School of Business.

Rice, R. E. \& Aydin, C. (1991). Attitudes toward new organizational technology: network proximity as a mechanism for social information processing. Administrative Science Quarterly, 2, 219-244. http://dx.doi.org/10.2307/2393354

Salter,A., Bruneel, J., \& D’Este, P. (2009). Investigating the factors that diminish the university-industry collaboration. Paper Presented at the Summer Conference on Copenhagen Business School.

Schienstock, G. (2009). Organizational capabilities: some reflections on the concepts. Research unit for technology, science and innovation. University of Tampere.

Sminia, H. (2003). The failure of the sport7 TV-channel: controversies in a business network. Journal of Management Studies, 40(7), 1621-1649. http://dx.doi.org/10.1111/1467-6486.00394

Tarricone, P., \& Luca, J. (2002) Successful teamwork: A case study. In Proceedings of the 25th HERDSA annual conference (pp. 640-646). HERDSA.

Taylor, M., \& Doerfel, M. L. (2003). Building inter organizational relationships that build nations'. Human Communication Research, 29(2), 153-181. http://dx.doi.org/10.1111/j.1468-2958.2003.tb00835.x

Tichy, N. M., Tushman, M. L., \& Fombrun, C. J. (1980). Network analysis in organizations. In E. E. I. Lawler \& D. A. Nadler, \& C. Cammann (Eds.), Organizational assessment - Perspectives on the measurement of organizational behavior and the quality of work life (pp. 372-398). New York: John Wiley \& Sons.

Tsai, W. (2001). Knowledge transfer in intra organizational networks: Effects of network position and absorptive capacity on business unit innovation and performance. Academy of Management Journal, 44, 996-1004. http://dx.doi.org/10.2307/3069443

Turner, M. E., \& Pratkanis, A. R. (1998). Twenty-five years of groupthink theory and research: Lessons from the evaluation of a theory. Organizational Behavior and Human Decision Processes, 73(2-3), 105-115. http://dx.doi.org/10.1006/obhd.1998.2756

Uzzi, B. (1996). The sources and consequences of embeddedness for the economic performance of organizations: The network effect. American Sociological Review, 61, 674-698. http://dx.doi.org/10.2307/2096399

Uzzi, B. (1997). Social structure and competition in inter firm networks: The paradox of embeddedness. Administrative Science Quarterly, 42, 35-67. http://dx.doi.org/10.2307/2393808

Uzzi, B. (1999). Social relations and networks in the making of financial capital. American Sociological Review, 64, 481-505. http://dx.doi.org/10.2307/2657252

Van Alstyne, M. (1997). The state of network organization: A survey in three frameworks. Journal of Organizational Computing, 7(3), 110-124.

Van de Bunt, G. G., Wittek, R. P. M., \& de Klepper, M. C. (2005). The evolution of intra-organizational trust networks. International Sociology, 20(3), 339-369. http://dx.doi.org/10.1177/0268580905055480

Van den Bulte, C., Lievens, A., \& Moenaert, R. K. (2001). Social networks, knowledge spillovers, and absorption within marketing departments. Unpublished manuscript.

Von Krogh, G., Nonaka, I., \& Nishiguchi, T. (2000). Knowledge creation, a source of value. MacMillan Press, London. http://dx.doi.org/10.1007/978-1-349-62753-0

Walker, G., Kogut, B., \& Shan, W. (2000). Social capital, structural holes and the formation of an industry network. In Lesser, E. L. (Ed.), Knowledge and social capital - foundations and applications (pp. 225-254). Boston: Butterworth Heinemann. http://dx.doi.org/10.1016/B978-0-7506-7222-1.50013-1

Zellmer-Bruhn, M. E. (2003). Interruptive events and team knowledge acquisition. Management Science, 49, 514-528. http://dx.doi.org/10.1287/mnsc.49.4.514.14423 
Prasetyo, A. H., \& Hu, J. 